\title{
Universities Development Data Analysis. A Case Study
}

\author{
Albina Gazizulina ${ }^{1,2 *}$ \\ ${ }^{1}$ Peter the Great St.Petersburg Polytechnic University, Polytechnicheskaya, 29, St.Petersburg, 195251, \\ Russia \\ ${ }^{2}$ Far Eastern State Technical Fisheries University, Lugovaya 52B, Vladivostok, 690087 Russian \\ Federation
}

\begin{abstract}
Statistical accounting of universities in the Russian Federation is available to any prospective students or organizations worldwide. The purpose of collecting statistical reports is to demonstrate the indicators and achievements of the university for applicants who choose a university for their further study and for organizations that would like a partnership with the university. Besides, this statistical collection is an effective tool for assessing the quality of the university administration's work, including monitoring the level of academic staff salaries and researchers. Therefore, the adequacy, and reliability of the information in the data of statistical reports is an extremely relevant and important task.
\end{abstract}

\section{Introduction}

Annually educational organizations in Russia conduct self-examination and analysis (monitoring) of performance indicators in order to establish compliance with the conditions for the implementation of the educational process, the content and quality of graduate training. The results of such self-examination and monitoring include analytical part and performance indicators. The data are published on the websites of universities and the Ministry of Education and Science in order to ensure the availability and openness of information. Anyone from anywhere in the world can examine them. This is important when choosing a university. Thus, monitoring carried out by the Ministry of Science and Higher Education solves the problem of attracting students from other regions and countries. Data collection has been carried out since 2011. During this time, a large database has been created that stores information on all universities in the country, including their branches. This monitoring involves not only state universities, but also private ones. Based on this analysis, the Ministry of Education and Science decides on the effectiveness of universities. Inefficient universities are revoked and closed. Thus, monitoring is an effective tool for applicants, students, employers and university founders. At the same time, the Ministry annually supplements the monitoring forms.

\footnotetext{
* Corresponding author: albinagazizulina@gmail.com
} 


\section{The main part}

Description of the statistical reporting model of Russian universities.

The statistical collection results of information are presented on the website https://monitoring.miccedu.ru/. This site is targeted only at the user who speaks Russian. The structure of the university's statistical analysis is given as follows [1]:

I. General information (Fig. 1). This section includes the following information:

- Name of the educational organization;

- Region and address of the organization;

- Departmental affiliation (for example, the university is subordinate to the Federal Agency for Maritime and River Transport);

- website hosted by the university;

- Founder (s) (for example, the university is subordinate to the Federal Agency for Maritime and River Transport)

- Profile of the organization (for example, educational organizations with no specific activity)

- List of organization's branches implementing higher education programs.

\begin{tabular}{|c|c|}
\hline $\begin{array}{l}\text { Name of the } \\
\text { educational } \\
\text { organization }\end{array}$ & $\begin{array}{l}\text { Federal state budgetary educational institution of higher } \\
\text { professional education «Far Eastern State Technical Fisheries } \\
\text { University» }\end{array}$ \\
\hline Region, address & 690087, Primorsky Territory, Vladivostok, Lugovaya st., 52-B \\
\hline $\begin{array}{l}\text { Departmental } \\
\text { subordination }\end{array}$ & The Federal Agency for Fisheries \\
\hline Website & http://www.dalrybvtuz.ru \\
\hline Founder(s) & The Federal Agency for Fisheries \\
\hline $\begin{array}{l}\text { Organization } \\
\text { profile }\end{array}$ & Educational organizations that do not have specific activities \\
\hline
\end{tabular}

Fig. 1. Information provided in the section "General information".

II. Performance monitoring indicators data (Table 1). This is one of the key sections if you want to evaluate a university on complex, integrated indicators [2-4]. This section is interesting for city administrations and ministries; it compares universities in the region or departmental affiliations. This section contains the following information:

- The organization's positions on the main indicators in comparison with the threshold values.

Table 1. Integral indicators of the Russian Federation's university.

\begin{tabular}{|c|c|c|c|c|c|c|}
\hline \multirow{2}{*}{ No } & \multirow{2}{*}{ Indicator } & \multirow{2}{*}{ Value } & \multicolumn{3}{|c|}{ Median values for } & $\begin{array}{c}\text { Change } \\
\text { over the } \\
\text { previous } \\
\text { year }\end{array}$ \\
\cline { 4 - 7 } & & & $\begin{array}{c}\text { Russian } \\
\text { Federation }\end{array}$ & $\begin{array}{c}\text { Federal } \\
\text { subject }\end{array}$ & $\begin{array}{c}\text { Departmental } \\
\text { subordination }\end{array}$ & \\
\hline E.1 & $\begin{array}{c}\text { Educational } \\
\text { activity }\end{array}$ & 53,00 & 63,31 & 53,99 & 55,45 & $+4,5 \%$ \\
\hline
\end{tabular}




\begin{tabular}{|c|c|c|c|c|c|c|}
\hline E. 2 & $\begin{array}{l}\text { Research } \\
\text { activity }\end{array}$ & 85,77 & 103,30 & 95,70 & 86,40 & $-39,9 \%$ \\
\hline E. 3 & $\begin{array}{l}\text { International } \\
\text { activity }\end{array}$ & 23,73 & 5,92 & 8,30 & 9,85 & $+3,7 \%$ \\
\hline E. 4 & $\begin{array}{c}\text { Financial and } \\
\text { economic } \\
\text { activities }\end{array}$ & 5931,61 & 2979,30 & 5712,20 & 4581,70 & $+12,9 \%$ \\
\hline E. 5 & $\begin{array}{c}\text { Academic staff } \\
\text { salaries }\end{array}$ & 203,43 & 209,30 & 206,80 & 203,40 & $+0,1 \%$ \\
\hline E. 8 & $\begin{array}{l}\text { Additional } \\
\text { indicator }\end{array}$ & 2,57 & 3,39 & 2,93 & 3,20 & $+4,0 \%$ \\
\hline
\end{tabular}

III. Results of monitoring the educational organization by areas of activity.

Educational activity (Fig. 2). This section involves basic information about the points that an applicant has to get to enter the university, the number of teachers, etc. This section compares universities in terms of educational performance. Actually, universities compete in terms of the scores of enrolled students [5-7].

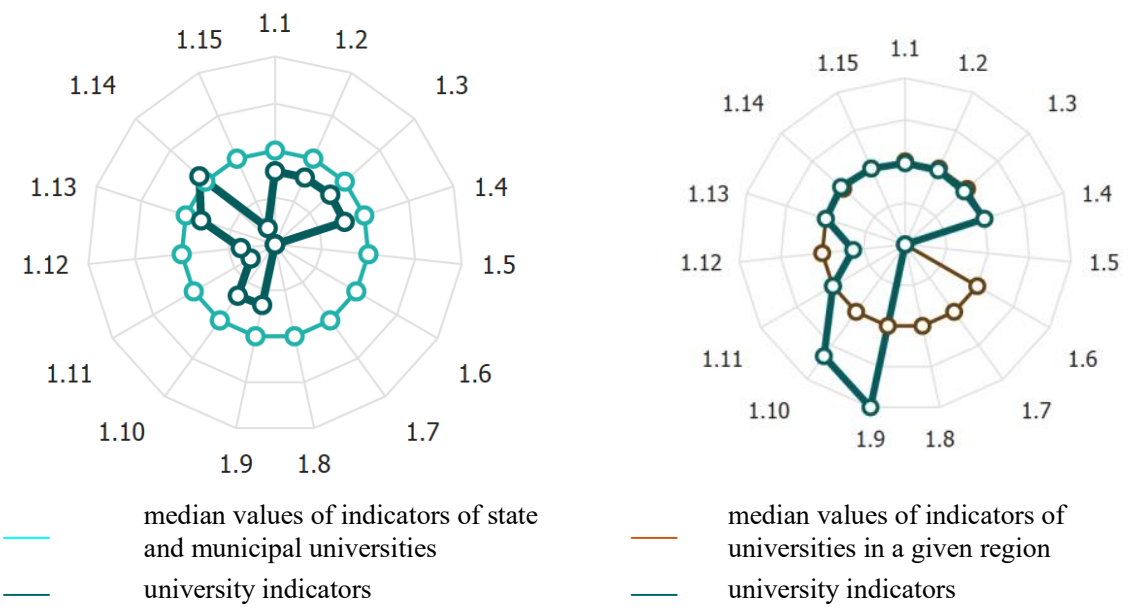

Fig. 2. Results of monitoring the educational organization on educational activities.

The indicators for monitoring educational activities presented in Figure 2 are shown in Table 2 .

Table 2. Integral indicators of the Russian Federation's university.

\begin{tabular}{|c|c|c|c|}
\hline № & Indicator & Units & Value \\
\hline 1.1 & $\begin{array}{c}\text { The average score of the Unified State } \\
\text { Exam (USE) of students accepted } \\
\text { according to USE results at the expense of } \\
\text { the corresponding budgets of the budgetary } \\
\text { system of the Russian Federation }\end{array}$ & score & 54,04 \\
\hline
\end{tabular}




\begin{tabular}{|c|c|c|c|}
\hline 1.2 & $\begin{array}{l}\text { The average USE score of university } \\
\text { students accepted according to USE results } \\
\text { without target quotas }\end{array}$ & score & 54,04 \\
\hline 1.3 & $\begin{array}{l}\text { The average USE score of students } \\
\text { admitted based on USE results with } \\
\text { payment of the cost of training costs by } \\
\text { individuals and legal entities }\end{array}$ & score & 48,55 \\
\hline 1.4 & $\begin{array}{l}\text { The average minimum score of the Unified } \\
\text { State Exam for students by sectors of } \\
\text { activity (specialty) }\end{array}$ & score & 38,76 \\
\hline 1.5 & $\begin{array}{l}\text { Students, winners, and prize-winners of the } \\
\text { final stage of the All-Russian Olympiad of } \\
\text { schoolchildren }\end{array}$ & people & 0 \\
\hline 1.6 & $\begin{array}{l}\text { Students, winners, and prize-winners of the } \\
\text { Olympiads of schoolchildren accepted for } \\
\text { full-time education for the first year }\end{array}$ & people & 0 \\
\hline 1.7 & $\begin{array}{l}\text { Students accepted according to the results } \\
\text { of the target admission }\end{array}$ & people & 0 \\
\hline 1.8 & $\begin{array}{l}\text { The percentage of students accepted } \\
\text { according to the results of the target } \\
\text { admission }\end{array}$ & $\%$ & 0 \\
\hline 1.9 & $\begin{array}{l}\text { The percentage of students enrolled in } \\
\text { master's programs }\end{array}$ & $\%$ & 6,42 \\
\hline 1.10 & $\begin{array}{l}\text { The percentage of students in master's and } \\
\text { postgraduate programs }\end{array}$ & $\%$ & 8,64 \\
\hline 1.11 & $\begin{array}{l}\text { The percentage of students with a } \\
\text { bachelor's, specialist's or master's degree } \\
\text { from other organizations admitted to the } \\
\text { first year of study in master's programs }\end{array}$ & $\%$ & 6,82 \\
\hline 1.12 & $\begin{array}{l}\text { The percentage of students enrolled in } \\
\text { master's and postgraduate programs with a } \\
\text { bachelor's degree, specialist diploma, or } \\
\text { master's degree from other organizations }\end{array}$ & $\%$ & 21,83 \\
\hline 1.13 & Graduate students per 100 students & people & 2,55 \\
\hline 1.14 & $\begin{array}{l}\text { The percentage of students from third-party } \\
\text { organizations who have completed training } \\
\text { under advanced training or professional } \\
\text { retraining programs }\end{array}$ & $\%$ & 94,50 \\
\hline
\end{tabular}




\begin{tabular}{|c|c|c|c|}
\hline 1.15 & $\begin{array}{c}\text { The percentage of students studying in the } \\
\text { fields of knowledge "Engineering, } \\
\text { technology, and technical sciences", } \\
\text { "Health and medical sciences", "Education } \\
\text { and pedagogical sciences", which have } \\
\text { signed agreements on employer-sponsored } \\
\text { education }\end{array}$ & $\%$ & 0,48 \\
\hline
\end{tabular}

Research activities (Fig. 3). The key indicators for assessing scientific activity are the volume of scientific research, expressed in money and the number and quality of scientific publications, in the number of employees who have a scientific degree as well $[8,9]$.

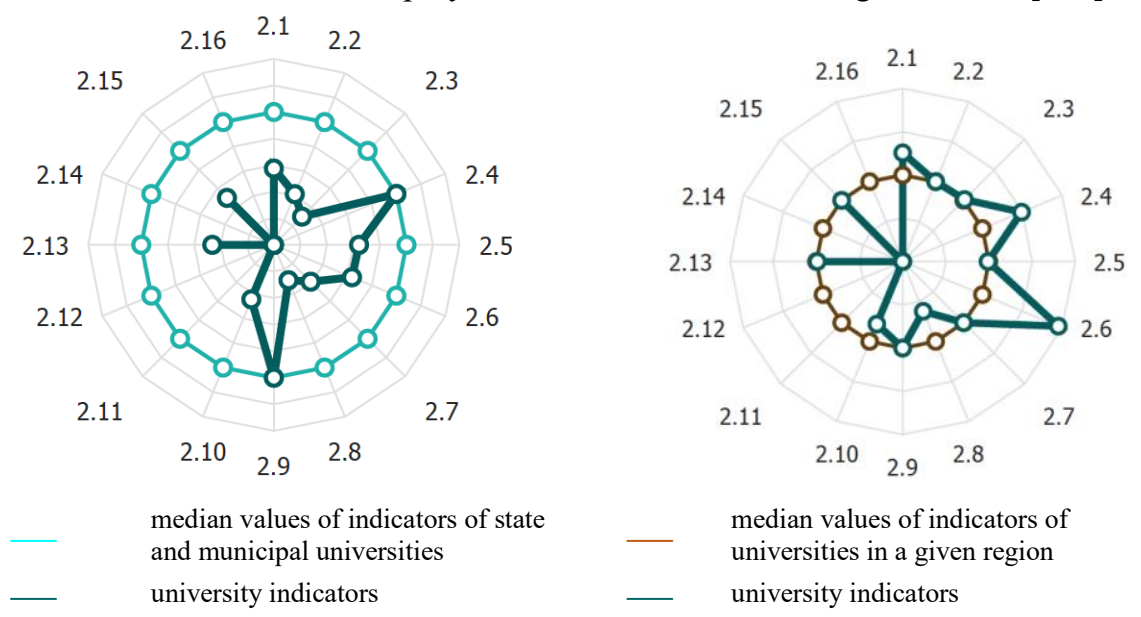

Fig. 3. Results of monitoring the educational organization on educational activities. 3.

The indicators for monitoring scientific activity given in Figure 3 are presented in Table

Table 3. Indicators of scientific activity monitoring

\begin{tabular}{|c|c|c|c|}
\hline № & Indicator & Units & Value \\
\hline 2.1 & $\begin{array}{l}\text { Citations of publications published over the } \\
\text { past } 5 \text { years, indexed at Web of Science } \\
\text { Core Collection per } 100 \text { employees }\end{array}$ & units & 37,52 \\
\hline 2.2 & $\begin{array}{l}\text { Citations of publications published over the } \\
\text { past } 5 \text { years, indexed at Scopus per } 100 \\
\text { employees }\end{array}$ & units & 52,41 \\
\hline 2.3 & $\begin{array}{c}\text { Citations of publications published over the } \\
\text { past } 5 \text { years, indexed at RSCI per } 100 \\
\text { employees }\end{array}$ & units & 274,76 \\
\hline 2.4 & $\begin{array}{l}\text { Publications indexed at Web of Science } \\
\text { Core Collection per } 100 \text { employees }\end{array}$ & units & 12,14 \\
\hline 2.5 & $\begin{array}{l}\text { Publications indexed at Scopus per } 100 \\
\text { employees }\end{array}$ & units & 15,45 \\
\hline 2.6 & $\begin{array}{c}\text { Publications indexed at RSCI, per } 100 \\
\text { employees }\end{array}$ & units & 172,14 \\
\hline 2.7 & $\begin{array}{c}\text { Total volume of research and development } \\
\text { work (R\&D) }\end{array}$ & $\begin{array}{l}\text { thousand } \\
\text { rubles }\end{array}$ & 15546,30 \\
\hline 2.8 & The share of income from $R \& D$ & $\%$ & 1,45 \\
\hline
\end{tabular}




\begin{tabular}{|c|c|c|c|}
\hline 2.9 & $\begin{array}{c}\text { The share of R\&D performed by own } \\
\text { forces (without the involvement of co- } \\
\text { executors) }\end{array}$ & $\%$ & 100,00 \\
\hline 2.10 & R\&D revenues per employee & $\begin{array}{c}\text { thousand } \\
\text { rubles }\end{array}$ & 39,70 \\
\hline 2.11 & License agreements & units & 0 \\
\hline 2.12 & $\begin{array}{c}\text { The share of funds obtained from the use } \\
\text { of the results of intellectual activity by an } \\
\text { educational organization }\end{array}$ & $\%$ & 4,76 \\
\hline 2.13 & $\begin{array}{c}\text { The share of the number of employees } \\
\text { without an academic degree - up to 30 } \\
\text { years, candidates of science - up to 35 } \\
\text { years, doctors of science - up to 40 years }\end{array}$ & $\%$ & 0 \\
\hline $\begin{array}{c}\text { The proportion of scientific and } \\
\text { pedagogical workers who defended their } \\
\text { candidate and doctoral dissertations in the } \\
\text { reporting period }\end{array}$ & $\%$ & 1 \\
\hline 2.14 & $\begin{array}{c}\text { Scientific journals, including electronic } \\
\text { ones, published by the educational } \\
\text { organization }\end{array}$ & units & 0 \\
\hline 2.16 & $\begin{array}{c}\text { Grants obtained for the reporting year per } \\
\text { 100 employees }\end{array}$ & units & 0 \\
\hline
\end{tabular}

\section{Reliability and adequacy of data collection information}

Data collection is carried out in 2 stages. The first part is collected from the statistical forms of VPO-1 and includes information on the students and staff of the university, an analysis of the areas of training in terms of demand by applicants, employers, and the ministry. It is from this part that it is possible to assess with what points and in what directions applicants enter, which areas are in demand by foreign students.

The second part includes the financial indicators of universities, analysis of the state of the university campus, analysis of the resource base, the provision of dormitories, analysis of publication activity, analysis of research projects, grants, the provision of libraries, etc.

Collecting data is a time-consuming task because the software is not integrated with the universities' databases; it is impossible to enter data simultaneously from several workplaces. As a result, human-made mistakes can be made during input and analysis. Despite the software is improved every year, nevertheless, it has some shortcomings and problems. For example, in the guidelines, it is said that the data have to correspond to certain statistical forms, and in fact, the number of cells for input is either more or less than the specified one[10, 11].

All monitoring consists of 8 large sections, includes a huge amount of data. It should be noted that this monitoring has a section on Employment of graduates. The Committee on Labor and Employment of the Population fills in this indicator. Applicants can easily analyze the monitoring of the employment of graduates of competing universities, the average salary of graduates of competing universities, and choose admission. Given the fact that documents are accepted online, applicants from the regions can choose any university. The Pension Fund of the Russian Federation, Federal Service for Supervision of Education and Science and labor and employment committees in the regions provide employment-monitoring data. Industry universities do not assess this indicator, since most often $100 \%$ of applicants are trained at the request of their founder [12-14]. 


\section{Discussion and Conclusion}

The main principles of monitoring conducted by the Ministry of Science and Higher Education of the Russian Federation are:

- openness and publicity of events and data during monitoring

- continuity and comparability of indicators

- taking into account the specifics of the activities of educational organizations in the formation of monitoring indicators

- the possibility of documentary confirmation of the quality of data provided by educational organizations

- the ability to obtain data on educational data from external sources.

The following groups of educational institutions of higher education are distinguished, which have the specifics of their activities:

- medical focus

- agricultural focus

- creative focus

- sports orientation

- transport orientation

The stages of monitoring are determined:

- determination of key areas of activity of educational organizations;

- development of indicators for their assessment;

- collection and verification of primary statistics data.

Data analysis and preparation of proposals are being carried out:

the indicators of the effectiveness of the activities of educational organizations and branches are calculated; boundary values are determined based on the median values of indicators within reference groups (federal districts of the Russian Federation, groups of regions, groups of organizations with a specific sectoral focus of activity; the results of monitoring are published in an open-source.

The article is published within the "Development of a Competitiveness Enhancement Methods of Fishing Fleet" (No.121031300159-6) government program of the Federal Agency for Fishery.

\section{References}

1. Monitoring the performance of higher education organizations URL: https://monitoring.miccedu.ru/

2. T. Minami \& Ohura, Y, Small data analysis for bigger data analysis. Paper presented at the ACM International Conference Proceeding Series, pp. 1-8, 2021, doi:10.1145/3456389.3456404

3. L. He, Innovation strategy of network ideological and political education based on big data. Paper presented at the Journal of Physics: Conference Series, 2021, 1852(3), doi:10.1088/1742-6596/1852/3/032021

4. Klochkov, Y., Akri, E., Samorukov, V., \& Evdokimov, K. (2019). Ranking assessment of the competitiveness of agricultural universities. Paper presented at the IOP Conference Series: Materials Science and Engineering, , 666(1) doi:10.1088/1757899X/666/1/012073.

5. I. C. Dos Santos Marques, Theiss, L. M., Johnson, C. Y., McLin, E., Ruf, B. A., Vickers, S. M., Chu, D. I. Implementation of virtual focus groups for qualitative data collection in a global pandemic. American Journal of Surgery, 221(5), pp. 918-922, 2021, doi:10.1016/j.amjsurg.2020.10.009 
6. J. Fan, Wang, W., Lin, H., Y. Liu, and C. Liu, Process-oriented definition of evaluation indicators, learning behavior collection and analysis: A case study, 2021, doi:10.1007/978-981-16-1160-5_29

7. V. Demidov, D. Mokhorov, A. Mokhorova, and Semenova, K., Professional public accreditation of educational programs in the education quality assessment system. Paper presented at the E3S Web of Conferences, p. 244, 2021, doi:10.1051/e3sconf/202124411042

8. E. Shirinkina, N. Strih, and E. Popova, Intellectual analysis of education data. Paper presented at the E3S Web of Conferences, p. 270, 2021, doi:10.1051/e3sconf/202127001004

9. A. G. Voronov, G. B. Voronov, D. G. Voronov, and I. Y. Nefedov, Trends and prospects of the educational technologies development. Paper presented at the Proceedings - 2021 1st International Conference on Technology Enhanced Learning in Higher Education, TELE 2021, pp. 115-118, 2021, doi:10.1109/TELE52840.2021.9482523

10. P. Swuste, A. Galera, W. Van Wassenhove, J. P. Carretero-Gómez, Arezes, J. KivistöRahnasto, C. Van Den Broeke, Quality assessment of postgraduate safety education programs, current developments with examples of ten (post)graduate safety courses in europe. Safety Science, 141, 2021, doi:10.1016/j.ssci.2021.105338

11. S. Sergeev, S. Barykin, O. Kalinina, E. Naumova, Dedyukhina, N., and Dmitrieva, T., Optimizing the energy efficiency of higher education institutions. Paper presented at the E3S Web of Conferences, p. 244, 2021, doi:10.1051/e3sconf/202124411029

12. L. Maksimenko, O. Korobova, V. Kalyuzhin, N. Ivantcivskaya, and I. Makarikhina, Tools of distance learning educational process at an engineering university. Paper presented at the E3S Web of Conferences, p. 210, 2020, doi:10.1051/e3sconf/202021022011

13. S. Storozheva, A. Popova, N. Mikidenko, A. Borisova, and E. Borisova, Information technologies in evidence-based education. Paper presented at the International Conference of Young Specialists on Micro/Nanotechnologies and Electron Devices, EDM, pp. 572-576, 2021, doi:10.1109/EDM52169.2021.9507567 